УДК 378

DOI 10.11603/me.2414-5998.2019.3.10652

Ya. M. Nakhaieva

ORCID 0000-0002-6556-0725

ResearcherID Q-6247-2016

I. R. Humenna

ORCID 0000-0002-2830-7878

ResearcherID Q-5206-2016

\author{
I. Horbachevsky Ternopil State Medical University
}

\title{
FORMING THE PROFESSIONAL COMPETENCE OF FUTURE DOCTORS AS A PEDAGOGICAL PROBLEM WHEN STUDYING FOREIGN LANGUAGES
}

\author{
Я. М. Нахаєва, I. Р. Гуменна \\ ДВНЗ «Тернопільський державний медичний університет \\ імені І. Я. Горбачевського МОЗ Украӥни»
ФОРМУВАННЯ ПРОФЕСІЙНОЇ КОМПЕТЕНТНОСТІ МАЙБУТНІХ ЛІКАРІВ ЯК ПЕДАГОГІЧНА ПРОБЛЕМА ПІД ЧАС ВИВЧЕННЯ \\ IНОЗЕМНИХ МОВ
}

\begin{abstract}
The main objectives of higher medical education are professional improvement of physicians to meet the needs dictated by the modern world both at undergraduate and postgraduate levels. Education of the future takes on the features of innovative education integrated with research activity, characterized by a continuous, fundamental, practical orientation. The article deals with the problem of the formation of the professional competence of future doctors in the study of foreign languages in medical institutions of higher education. It is noted, that modern education programmes, introduced as a result of the reform of medical education, are built not only on the principle of knowledge and skills obtaining, but also the acquisition of competencies. Modern trends in planning, organizing, evaluating the quality of education actually helped to ensure the implementation of competence-based approach in the training of doctors. The theoretical aspects of this problem are also considered.

The research has identified the need to develop methodological materials for focusing on and developing the future doctors during studying of foreign languages.

Key words: professional competence; competence; efficient education; educational space; foreign languages.

Анотація. Основними завданнями вищої медичної освіти є професійне вдосконалення лікарів для задоволення потреб, продиктованих сучасним світом, як на рівні студентів, так і аспірантів. Навчання майбутнього набуває особливостей інноваційної освіти, інтегрованої з науково-дослідною діяльністю, що характеризується постійною, фундаментальною, практичною спрямованістю. У статті розглядається проблема формування професійної компетентності майбутніх лікарів під час вивчення іноземних мов у медичних закладах вищої освіти. Зроблено наголос на тому, що сучасні навчальні програми, які впроваджені внаслідок реформи медичної освіти, побудовані не лише за принципом здобуття знань та умінь, а й набуття компетенцій. Сучасні тенденції планування, організації, оцінки якості освіти фактично допомогли забезпечити впровадження компетентнісного підходу в підготовці лікарів. Розглянуто також теоретичні аспекти цієї проблеми.

Дослідження довело необхідність розробки методичних матеріалів для цілеспрямованого формування професійної підготовки майбутніх лікарів під час вивчення іноземних мов.

Ключові слова: професійна компетентність; компетенція; продуктивна освіта; освітній простір; іноземні мови.
\end{abstract}

Introduction. Integration of Ukraine into the European educational space requires a high level of professional activity of doctors. Modern medical workers must have stronger knowledge and skills, professional qualities, psychological and pedagogical

(C) Ya. M. Nakhaieva, I. R. Humenna abilities that enable them to find optimal, independent decisions in non-standard situations. In this context, only professionally trained specialist can exceed supplies unplanned, over-normative, and he can approve correct, well-founded decision and also to carry responsibility for it. 
The aim - to study the problem of forming the future doctors' professional competence in examining foreign languages.

Theoretical framework. A problem of forming of future doctors' professional competence was the object of many scientific researches. In particular, I. Boitsova was deciding problems of foreign language communicative competence formation; $\mathrm{H}$. Klishch was researching issues of professional competence as the goal of training modern physicians at Austrian medical universities; O. Sidelkovskyi was considering increasing the competence of the doctor in the branch of medical ethics; M. Noskova was engaged in the research of the future doctors' communicative competence; N. Rusyna was reporting about perspectives of assessing the competence of a future medical specialist and others. However, the question of the formation of students' professional competence of medical universities is not revealed in all aspects.

Perceiving new role of education in modern society, it is appropriate to separate out the actual problem of ensuring and improving the quality of higher education relevant to all countries of the world. It has been determined, that the quality of higher education is the basis of development of the European Higher Education Area [2].

By satisfying the educational needs of the person and community in qualified specialists, the state must not only control the results of educational activities of all its participants at all stages, but also guarantee the quality of education. The problem of quality ensuring, which is considered as a characteristics complex of the subject of activity, relating to his ability to meet the established and foreseen needs of education, is complex: scientific, technical, economic, social [2].

The quality of higher education is established on the basis of professional competence, namely: by means of the compliance of the graduates of the medical institutions of higher education with the dynamic requirements of the socio-economic and cultural-professional spheres of life. The appeal to the problem of the professional competence formation is due to the increased requirements of the labor market to the professionalism of a specialist, as well as such changes in the market of educational services as competition and the introduction of new technologies. Formation of professional competence is important in any field of activity. This problem is particularly acute when readiness for a certain type of professional activity is only formed, in the stage of formation, as the case during the training of future doctors in the process of studying foreign languages. Modern transformations in society require from the medical schools of higher education the training of a competent specialist who will be able to provide the necessary and qualified treatment.

Professional competence of the doctors has an integral characteristic that determines the ability to solve various problems and health problems using the knowledge and professional experience.

The professional competence of a doctor is a complex of crucial, basic and special competence. Core competencies are required for any professional activity, they are related to the success of the individual in the current conditions and realities of life. Core competencies are becoming more important today. Primarily, they are manifested in the ability to decide professional problems on the basis of the use of information, communication in a foreign language, in the socio-legal bases of the behavior of the person in a civilized society. Core competence is not only revealed in decision of professional tasks, but also how the specialist perceives and understands the world outside of his profession.

Basic competencies reflect the specifics of a particular professional activity, such as medical. The profession of physician is based on the competencies necessary for the organization of professional activities of a medical worker in the context of modern requirements for the health system [1].

Special competencies reflect the specifics of a particular area of professional activity. Special competencies can be considered as the implementation of crucial and basic competencies in a particular area of professional activity. All three types of competencies are interconnected and evolving simultaneously. This forms the individual style of doctor's professional activity, creates a holistic appearance of a medical worker with a higher education and ensures the formation of his professional competence, as an integrative, competitive, personal characteristic.

Competences are generalized methods of action that ensure the productive performance of professional activities [1]. Regarding medical activity, it reflects the doctor's ability to practice professional competence. The clusters of competences serve as a foundation that enables the future doctor to clearly navigate the labor market and be trained in self-education, advanced and post-graduate training. The quality of higher education is influenced by many factors that act independently or interrelated. An important guarantee of quality is its standardization. 
Standardization refers to a fully range of issues that relate to the value of standards and their impact on the quality of education. An explorations revealed that standardization can be viewed as an organized activity to achieve an optimal level of regulation in a particular industry by setting provisions for general and reusable use of real or existing tasks. It is a unique area of social activity that synthesizes scientific, technical, economic, legal, aesthetic and political aspects.

The principles of standards, which are the organizational and technical basis of the management and quality control system, is based on the close interconnection of all its elements, which provide a stable high performance.

The process of creating, implementing and maintaining a system of quality indicators in order to streamline activities is a complex multi-component task that should be meaningful and feasible. It is known that the implementation of the standard is appropriate if it gives the expected result [3].

The structure of the system of higher education standards is a complex of interconnected standards that constitute requirements for the content, volume and level of quality of higher education. The main component of the state standards of higher education of doctors determines the structure of specialties list, which are the training of specialists in higher educational institutions for the relevant educational qualifications, as well as the requirements for each educational qualification level and the corresponding educational level.

Introduction of the system of standards promotes higher level of organization and quality of higher education, allows effective implementation of a uniform state policy in the field of education, protects the interests of consumers of educational services, ensures interchangeability and compatibility of various educational qualification levels, creates conditions for the integration of the national system of higher education into the international scientific-educational community.

It is about the degree of standardization of higher education, which in this case is considered as the normative basis for the functioning of the higher education system, which establishes the general principles of future professional activities of the doctor aimed at achieving the optimal level of regulation in the field of higher medical education [3].

In this context, V. Bondar's opinion deserves attention that the introduction of European norms and stan- dards in education, science and technology, as well as the expansion of its own cultural and scientific and technological achievements in the sphere of education, science and technology integration of Ukraine into the European Union [3]. Thus, it will work to increase the European cultural identity in Ukraine and integrate it into a European intellectual, educational and scientific and technical environment. Integration processes in the respective areas are the dissemination of their own cultural and scientific and technological achievements in the EU, and also the implementation of European norms and standards in education, science and technology, in accordance with the requirements of the International Standard Classification.

Ukraine has practically completed the development of the second, and from some directions - the third generation of higher education standards. It is noted that the new generation of normative and educationalmethodical documentation is based on the results of studying and forecasting the structure of social and production activities of specialists with higher education, taking into account the needs of the labor market.

The introduction of uniform and compulsory for all educational institutions of state standards allows to reserve a single educational space, to achieve the optimal level of regulation of activities in the field of higher education, but, like previous state standards, does not solve the problem of continuity of training programs for junior specialists and bachelors.

The lack of conformity between these standards does not allow a junior specialist to continue training in an approved state program. To acquire the next level of education, it can on the so-called "reduced" program, which is developed by the medical schools in individual order, by recounting already studied disciplines or their sections. The statute about educational qualification (degree education) guarantees that the term of their preparation for the next educational qualification level "bachelor" decreases for one to two years. This allows us to make assumptions about the different quality of undergraduate education based on full secondary education and on the basis of a junior specialist. Such modernization will be respond with the development of education in Ukraine in terms of ensuring its quality on the basis of adherence to state education standards [3].

Therefore, on the basis of the study of scientific literature and the synthesis of the results of the content of professional medical activities, in accordance with the standards of higher medical education, we distinguish 
the following groups of competences that provide for the formation of certain competencies:

- scientific, instrumental and informational and communicative competences reflect the focus on the formation of key competencies of the doctor;

- cultural, social, managerial, civil law, methodological, cognitive and general competences provide for the formation of basic competence of a medical worker;

- oriented, social-personal and personal competencies are diverted to the special competence of a medical specialist.

The competence of the doctor is considered as a part of the readiness of the doctor to innovate. The formation of professional competence in future doctors should be influenced since the first year of study. Therefore, searching of new methods for improving the professional competence for doctors involving advanced technologies is still in progress.

However, as the research shows, in the formation of the professional competence of the doctor, a special place is given to the study of foreign languages for the purpose of vocational training of a specialist. We studied the problem of speech support in the preparation of a future doctor, which, according to M. Sadova, will contribute to the formation and support of high-level students in foreign languages, which will facilitate the readiness of highly qualified doctors to innovate [4].

It is important to emphasize that the amount of speech readiness for the innovations of individual students is not identical to the readiness of the group. Social-psychological characteristics of specific groups is a factor that can significantly affect the ability to update the innovative potential of an educational institution. Therefore, the readiness of the future specialist is an important step in achieving general success.

Changes in the organizational development suppose information provision, which allows to optimize the whole process of educational innovations and increase

\section{List of literature}

1. Алексюк А. М. Педагогіка вищої освіти України. Історія. Теорія / А. М. Алексюк. - К. : Либідь, 1998. 560 c.

2. Ахмедзянова Л. М. Подготовка будущих учителей к воспитанию духовности у школьников / Л. М. Ахмедзянова, С. И. Иванников // Виховання і культура. - 2001. - № 1. - С. 14-17. the level of professional readiness of a student of a medical school.

The constant orientation of the student to improve himself as a subject of future professional activity generates a special sensibility of the doctor to the imperfection of the organizational aspect of work. Updates the possibility of joint activities of teachers and psychologists, which will create preconditions not only for the continuous engagement of students in collective work and will shape the installation of future doctors for change as a prerequisite for improvement in the direction of professional growth.

Thus, attracting students to self-change will encourage future doctors to receive new knowledge and skills in accordance with the requirements of educational programs [4].

Conclusions and Prospects for Research. The crucial competence forms and invariant part of the professional competence of a future doctors during of studying foreign languages based on the high level of language proficiency required for educational activities.

Basic competence is required for the professional activity of a specialist in medicine, it is firmly attached to the profession of a doctor, and also used by representatives of other professions, defining an invariant part of the basic competence of a specialist. Special competence plays a leading role in the realization of a particular type of professional activity. Special competence is a variational part of the professional competence of a health worker. Thus, only a part of the work done concerns the level of readiness for the professional activity of future doctors, the diagnosis of motivation for educational innovation activities and may be the subject of an open discussion.

Prospects for further scientific research we see in the development of methodological materials for focusing on and developing the future doctors in the study of foreign languages.

3. Бондар В. I. Дидактико-психологічна концепція реалізації освітньо-професійних програм підготовки вчителя / В. І. Бондар // Вища освіта України. - 2004. № 1. - С. 66-68.

4. Викулина М. А. Иноязычная коммуникативная компетентность преподавателя медицинского вуза / М. А. Викулина // Междунар. журн. экспериментального образования. - 2011. - № 4. - С. 59-62. 


\section{References}

1. Aleksiuk, A.M. (1998). Pedahohika vyshchoi osvity Ukrainy. Istoriia. Teoriia. [Pedagogy of higher education of Ukraine. History. Theory]. Kyiv: Lybid [in Ukrainian]. 2. Akhmedzianova, L.M. (2001). Podhotovka budushchykh uchyteley $\mathrm{k}$ vospytaniyu dukhovnosty u shkolnykov [Preparing future teachers for the education of spirituality in schoolchildren]. Vykhovannia i kultura - Education and Culture [in Ukrainian].

3. Bondar, V.I. (2004). Dydaktyko-psykholohichna kontseptsiia realizatsii osvitno-profesiinykh prohram pidho- tovky vchytelia [Didactics and psychological concept of realization of educational and professional teacher training programs]. Vyshcha osvita Ukrainy - Higher Education of Ukraine [in Ukrainian].

4. Vikulina, M.A. (2011). Inoyazychnaya kommunikativnaya kompetentnost prepodavatelya meditsinskogo vuza [Foreign language communication competence of the medical school teacher]. Mezhdunarodnyy zhurnal eksperimentalnogo obrazovaniya - International Journal of Experimental Education [in Ukrainian].

Received 12.03.19

Recommended 18.03.19

E-mail address for correspondence: nahaeva@tdmu.edu.ua 